\title{
Strategia utrzymania rytmu zatokowego u pacjentów z niezastawkowym migotaniem przedsionków - stan wiedzy, kontrowersje, toczące się badania*
}

\author{
Rhythm control strategy in patients with non-valvular atrial fibrillation \\ - current knowledge, controversy, ongoing research
}

\author{
Paweł Wałek ${ }^{1}$, Janusz Sielski ${ }^{1}$, Iwona Gorczyca ${ }^{1}$, Katarzyna Starzyk ${ }^{1}$, \\ Radosław Bartkowiak ${ }^{1}$, Beata Wożakowska-Kapłon ${ }^{1,2}$ \\ ${ }^{1}$ Świętokrzyskie Centrum Kardiologii Wojewódzkiego Szpitala Zespolonego w Kielcach \\ ${ }^{2}$ Wydział Lekarski Nauk o Zdrowiu Uniwersytetu Jana Kochanowskiego w Kielcach
}

\section{Streszczenie}

Podstawowym problemem terapeutycznym u chorego z migotaniem przedsionków (AF), poza ustaleniem wskazań do leczenia przeciwkrzepliwego, jest wybór strategii utrzymania rytmu zatokowego lub kontroli częstości rytmu komór. W wytycznych z 2016 roku zaleca się wybór strategii utrzymania rytmu zatokowego „tylko” w celu zmniejszenia objawów wynikających z arytmii. W dotychczas przeprowadzonych badaniach nad wyborem strategii leczenia u pacjentów z AF nie ujawniono przewagi jednej strategii nad drugą. W wieloośrodkowych badaniach, takich jak AFFIRM, RACE, STAF, PIAF, HOT CAFE, nie wykazano różnic między obiema strategiami pod kątem umieralności oraz częstości powikłań sercowo-naczyniowych, choć w wielu analizach post-hoc przedstawiono dowody przewagi strategii utrzymania rytmu zatokowego, uwzględniając tak zwane miękkie punkty końcowe, takie jak poprawa wydolności fizycznej czy poprawa profilu humoralnego. Mimo zalecanego w wytycznych paradygmatu utrzymania rytmu zatokowego "tylko" do poprawy w zakresie objawów u pacjenta, badania obserwacyjne wskazują, że pacjentów z przywróconym i utrzymanym rytmem zatokowym cechuje lepsze rokowanie. A artykule przedstawiono aktualny stan wiedzy dotyczący wyboru strategii postępowania u pacjentów z niezastawkowym AF.

Słowa kluczowe: migotanie przedsionków, kardiowersja, leczenie antyarytmiczne, doustne antykoagulanty

Folia Cardiologica 2017; 12, 6: 570-579

\section{Wstęp}

Podstawowym terapeutycznym problemem u chorego z migotaniem przedsionków (AF, atrial fibrillation), poza ustaleniem wskazań do leczenia przeciwkrzepliwego, jest wybór strategii utrzymania rytmu zatokowego lub kontroli częstości rytmu komór [1]. W wytycznych z 2016 roku zaleca się wybór strategii utrzymania rytmu zatokowego „tylko" w celu zmniejszenia objawów wynikających z arytmii. W dotychczas przeprowadzonych badaniach nad wyborem strategii leczenia u pacjentów z AF nie ujawniono przewagi jednej strategii nad drugą. W wieloośrodkowych badaniach, takie jak AFFIRM (Atrial Fibrillation Follow-up Investigation of Rhythm Management), RACE (RAte Control Versus Elec-

\footnotetext{
*Praca powstała w ramach realizacji projektu: „Zakup wyposażenia I Klinicznego Oddziału Kardiologii i Pracowni Elektrofizjologii szansą na zwiększenie innowacyjności Wojewódzkiego Szpitala Zespolonego w Kielcach" współfinansowanego przez Unię Europejską ze środków Europejskiego Funduszu Rozwoju Regionalnego w ramach Regionalnego Programu Operacyjnego Województwa Świętokrzyskiego na lata 2007-2013
}

Adres do korespondencji: lek. Paweł Wałek, Świętokrzyskie Centrum Kardiologii, Wojewódzki Szpital Zespolony, ul. Grunwaldzka 45, 25-736 Kielce, tel. 413671 510, e-mail: pawel.walek@o2.pl 
trical Cardioversion of Persistent Atrial Fibrillation), STAF (The Strategies of Treatment of Atrial Fibrillation), PIAF (Pharmacological Intervention in Atrial Fibrillation), HOT CAFE (How to Treat Chronic Atrial Fibrillation), nie wykazano różnic między obiema strategiami pod kątem umieralności ani częstości powikłań sercowo-naczyniowych, choć w wielu analizach post-hoc przedstawiono dowody przewagi strategii utrzymania rytmu zatokowego, uwzględniając tak zwane miękkie punkty końcowe, takie jak poprawa wydolności fizycznej czy profilu humoralnego [2-6]. Mimo zalecanego w wytycznych paradygmatu utrzymania rytmu zatokowego „tylko" do poprawy w zakresie objawów u pacjenta badania obserwacyjne wskazują, że osoby z przywróconym i utrzymanym rytmem zatokowym cechuje lepsze rokowanie [7-11].

\section{Wpływ wyboru strategii leczenia na rokowanie chorego}

Z badań obserwacyjnych wynika, że u pacjentów z utrzymanym rytmem zatokowym rokowanie jest lepsze, choć w prospektywnych, randomizowanych badaniach klinicznych nie udało się tego wykazać [7-11]. W badaniach obserwacyjnych Framingham Study i Olmsted Country Study dowiedziono mniejszej śmiertelności pacjentów z napadowym AF w porównaniu z chorymi z utrwalonym AF niezależnie od wieku (<75. rż., $\geq 75$. rż.) i płci $[7,8]$. Podobnie w badaniu lonescu-Ittu i wsp. [9], w populacji około 26 tys. pacjentów z Kanady, udowodniono wyższość strategii utrzymania rytmu zatokowego nad strategią kontroli częstości rytmu komór. W badaniu tym różnice na korzyść utrzymania rytmu zatokowego wykazano dopiero po 4 latach obserwacji. Ciekawym i zarazem niepokojącym był fakt wzrostu śmiertelności w grupie utrzymania rytmu zatokowego w pierwszych 6 miesiącach badania, następnie zanotowano spadek śmiertelności, co korelowało z ograniczeniem częstości przepisywania leków przeciwarytmicznych pacjentom z napadowym AF. Zmniejszenie częstości przepisywania leków przeciwarytmicznych zbiegło się z czasem opublikowania wyników badania AFFIRM, po którym dość krytycznie zaczęto podchodzić do stosowania wspomnianych leków w określonych grupach pacjentów. Różnic mogących wpłynąć na wyniki badań klinicznych i obserwacyjnych poszukuje się w charakterystyce badanych populacji, pewnych niedostatkach protokołu badań klinicznych oraz farmakoterapii przeciwarytmicznej.

Największym badaniem klinicznym dotyczącym wyboru strategii utrzymania rytmu zatokowego lub strategii kontroli częstości rytmu komór było badanie AFFIRM, którego wyniki opublikowano w 2002 roku. Włączono do niego 4060 pacjentów w średnim wieku 69,7 roku [12]. Wynikiem tego badania, który wpłynął na kolejne wytyczne dotyczące leczenia AF, była konkluzja, że pod względem umieralności strategia utrzymania rytmu serca nie jest lepsza od strategii kontroli częstości rytmu komór. W dobie aktualnej wiedzy na temat leczenia przeciwkrzepliwego i przeciwarytmicznego badanie to ma dwie podstawowe wady. Pierwsza to fakt, że pacjentom, którzy utrzymali rytm zatokowy przez 4 tygodnie pozwolono na odstawienie leków przeciwkrzepliwych niezależenie od ryzyka zakrzepowo-zatorowego. Fakt zaprzestania leczenia przeciwkrzepliwego u pacjentów z rytmem zatokowym wpłynął na większą częstość występowania udarów mózgu w tej grupie chorych, a tym samym mógł wpłynąć na umieralność, zmniejszając korzyści z utrzymania rytmu zatokowego. Na podstawie tej obserwacji badania AFFIRM wyciągnięto wniosek o konieczności kontynuacji leczenia przeciwkrzepliwego mimo utrzymania rytmu zatokowego u pacjentów z grupy wysokiego ryzyka zakrzepowo-zatorowego. Kolejnym zarzutem wobec badania AFFIRM jest dobór leczenia przeciwarytmicznego. W badaniu tym stosowano leki przeciwarytmiczne, takie jak chinidyna, morcizina, dizopiramid, prokainamid, propafenon, sotalol, dofetilid, flekainid, a także dopuszczono leczenie skojarzone. Niektóre z tych leków nie są już stosowane, a w przypadku chinidyny, dizopiramidu i sotalolu dowiedziono, że mogą zwiększać umieralność [13]. Kolejną niedoskonałością badania AFFIRM jest fakt, że pacjenci w okresie badania przechodzili z grupy kontroli rytmu do grupy kontroli częstości rytmu komór i odwrotnie. Podkreśla się także to, że średnia wieku pacjentów w badaniu AFFIRM wynosiła 69,7 roku, aktualnie jednak coraz częściej AF jest diagnozowane u pacjentów młodszych. Uwzględniając wyżej wymienione niedoskonałości opisywanego badania, w 2004 roku na łamach „Circulation” opublikowano analize post-hoc, która wykazała, że utrzymanie rytmu zatokowego u pacjentów nieprzerwanie przyjmujących warfaryne i niepoddanych leczeniu przeciwarytmicznemu zmniejsza liczbę zgonów. Podkreślono także potrzebę poszukiwania kolejnych, bezpieczniejszych metod utrzymywania rytmu zatokowego [10].

Na podstawie analizy baz danych z badań klinicznych i obserwacyjnych postawiono teze, że uzyskanie i utrzymanie rytmu zatokowego bezpieczniejszymi metodami terapii przełoży się na poprawę rokowania pacjentów z AF. Jednym z pierwszych randomizowanych badań klinicznych, w którym wykazano poprawę rokowania u pacjentów z AF z utrzymanym rytmem zatokowym, jest badanie ATHENA [14]. Oceniano w nim skuteczność i bezpieczeństwo stosowania dronedaronu u pacjentów z napadowym AF w utrzymaniu rytmu zatokowego oraz wpływ takiej terapii na rokowanie przedstawione jako punkt złożony, w którego skład wchodziły zmniejszenie częstości hospitalizacji z przyczyn sercowo-naczyniowych oraz zmniejszenie częstości zgonów z przyczyn sercowo-naczyniowych. W kolejnych badaniach i analizach post-hoc pozycja dronedaronu osłabła, a fakt zwiększania śmiertelności u pacjentów z utrwalonym AF i niewydolnością krążenia wykazana $w$ badaniu PALLAS (Permanent Atrial fibriLLAtion Outcome Study Using 
Dronedarone on Top of Standard Therapy) spowodowała, że jest on przeciwwskazany w tych grupach pacjentów.

Opublikowano pojedyncze doniesienia o zmniejszeniu umieralności oraz częstości udarów mózgu u pacjentów z AF, u których wykonano ablację AF i uzyskano utrzymanie rytmu zatokowego [15-17]. W bieżącym roku ukazał się artykuł Saliba i wsp. [11], w którym na podstawie analizy baz danych jednego ze świadczeniodawców usług medycznych w Izraelu przedstawiono wyniki sugerujące zmniejszenie umieralności, częstości przejściowych napadów niedokrwiennych (TIA, transient ischemic attack) i udarów mózgu o około $40 \%$ u pacjentów obciążonych dużym ryzykiem powikłań zakrzepowo-zatorowych, u których wykonano ablację AF. Mimo tych doniesień w aktualnych wytycznych dotyczących leczenia AF nie zaleca się zastosowania strategii utrzymania rytmu zatokowego w celu poprawy rokowania pacjentów, obejmującego śmiertelność ogólną, sercowo-naczyniową i udaru mózgu, a jedynie w celu zmniejszenia objawów związanych z chorobą.

W trakcie kongresu Europejskiego Towarzystwa Kardiologicznego (ESC, European Society of Cardiology) w BarceIonie w 2017 roku przedstawiono wyniki badania CASTLE-AF (Catheter ablation versus standard conventional treatment in patients with left ventricular dysfunction and atrial fibrillation). Dotyczyło ono pacjentów z niewydolnością serca z obniżoną funkcją skurczową mięśnia lewej komory i AF zakwalifikowanych do ablacji AF lub standardowego leczenia farmakologicznego i wykazano w nim, w grupie pacjentów poddanych ablacji, zmniejszenie umieralności o 47\%, śmiertelności sercowo-naczyniowej o 51\%, a także redukcję liczby epizodów nasilenia objawów niewydolności krążenia o 44\%. Pierwszorzędowy punkt końcowy, na który składały się ograniczenie umieralności z jakiejkolwiek przyczyny i obniżenie liczby epizodów nasilenia objawów niewydolności krążenia, wystąpił u $28,5 \%$ pacjentów poddanych ablacji i u 44,6\% w grupie objętej leczeniem standardowym (współczynnik ryzyka [HR, hazard ratio] 0,$62 ; p=0,007$ ). Wartym podkreślenia jest czas trwania obserwacji pacjentów, który wynosił 7 lat, a także fakt, że każdemu choremu implantowano kardiowerter-defibrylator, co pozwalało na bardzo dokładne monitorowanie nawrotu AF. Najlepsze wyniki badania wykazano u pacjentów około 64. wieku życia, w II klasie niewydolności według New York Heart Association (NYHA), z napadowym AF.

Spośród toczących się badań klinicznych służących ocenie strategii leczenia AF i wiążącego się z tym rokowania na szczególną uwage zasługują CABANA (Catheter Ablation vs Anti-arrhythmic Drug Therapy for Atrial Fibrillation Trial) oraz EAST (Early Treatment of Atrial Fibrillation for Stroke Prevention Trial). Badanie CABANA zaprojektowano, by sprawdzić hipotezę, zgodnie z którą ablacja przezcewnikowa AF jest lepsza niż farmakologiczna kontrola rytmu serca lub kontrola częstości rytmu komór [18]. Punktem pierwszorzędowym jest punkt złożony i składają się na nie- go umieralność, udar prowadzący do niepełnosprawności, poważne krwawienie oraz zatrzymanie krążenia. Badanie to obejmuje dodatkowe dwie grupy w celu porównania sposobów izolacji żył płucnych oraz farmakoterapii kontroli rytmu serca i kontroli częstości rytmu komór. Do badanej grupy są włączani pacjenci od 18. do 90. roku życia z udowodnionym AF, o podobnej charakterystyce jak w badaniu AFFIRM, których można leczyć obiema metodami (ablacja v. farmakoterapia). Pacjenci włączeni do badania będą oceniani co 6 miesięcy przez 5 lat. Autorzy tego badania, poza porównaniem leczenia farmakologicznego, zabiegowego oraz jakości życia, mają odpowiedzieć na pytanie, czy AF jest poddającym się modyfikacji czynnikiem ryzyka zgonu. Badanie CABANA rozpoczęto w 2009 roku, zakładając włączenie ponad 2200 pacjentów, a przewidywana data jego zakończenia to połowa 2018 roku.

Hipotezą badawczą w projekcie EAST jest twierdzenie, że wczesne leczenie kontrolujące rytm zatokowy u pacjentów z AF za pomocą leków przeciwarytmicznych i/lub ablacji może obniżyć ryzyko powikłań związanych z AF w porównaniu z postępowaniem mniej intensywnym. Pierwszorzędowy złożony punkt końcowy obejmuje zgon z przyczyn sercowo-naczyniowych, udaru mózgu oraz hospitalizacje z powodu niewydolności krążenia lub ostrego zespołu wieńcowego. Czas obserwacji wynosi 8 lat. Badanie rozpoczęło się w 2011 roku; włączono do niego 2789 pacjentów, a czas zakończenia badania wyznaczono na połowę 2019 roku [19]. Wartym podkreślenia jest czas obserwacji zaplanowany w badaniach CABANA i EAST, tj. 5 i 8 lat, ponieważ w najczęściej cytowanym badaniu w kontekście oceny strategii leczenia AF, czyli AFFIRM, średni czas obserwacji wynosił 3,5 roku.

Badaniem dotyczącym strategii utrzymania rytmu zatokowego u pacjentów z AF i implantowanym układem resynchronizującym jest polskie badanie Pilot-CRAfT (Comparison of the rhythm control treatment strategy versus the rate control strategy in patients with permanent or long-standing persistent atrial fibrillation and heart failure treated with cardiac resynchronization therapy - a pilot study of Cardiac Resynchronization in Atrial Fibrillation Trial) [20]. Służy ono ocenie strategii utrzymania rytmu zatokowego w porównaniu ze strategią kontroli częstości rytmu komór u pacjentów z przetrwałym lub długotrwale przetrwałym AF, którym implantowano układ resynchronizujący. Pierwszorzędowym punktem końcowym jest uzyskany odsetek stymulacji dwukomorowej w ciągu 12 miesięcy od randomizacji. W badaniu zaplanowano także wiele punktów drugorzędowych w zakresie oceny klinicznej, echokardiograficznej i elektrokardiograficznej (EKG). W grupie kontroli częstości rymu komór dopuszczono możliwość ablacji węzła przedsionkowo-komorowego w celu zwiększenia odsetka stymulacji dwukomorowej. Zaplanowano włączenie 60 pacjentów. Termin zakończenia badania to marzec 2017 roku [20]. 


\section{Kardiowersja farmakologiczna i elektryczna}

Strategia utrzymania rytmu zatokowego polega na przywróceniu prawidłowego rytmu zatokowego, czyli kardiowersji, a następnie utrzymaniu tego rytmu za pomocą leczenia przeciwarytmicznego lub ablacji. Przywrócenie rytmu zatokowego odbywa się samoistnie lub za pomocą kardiowersji farmakologicznej albo elektrycznej. Zgodnie z aktualnymi wytycznymi dotyczącymi leczenia AF kardiowersję elektryczną zaleca się u wykazujących objawy pacjentów z przetrwałym lub długotrwale przetrwałym AF. U chorych niestabilnych hemodynamicznie zaleca się natychmiastową kardiowersję elektryczną. Do kardiowersji farmakologicznej, zależnie od chorób towarzyszących, można zastosować propafenon, amiodaron, flekainid, ibutilid oraz wernakalant. W amerykańskich wytycznych dotyczących leczenia AF dopuszczono do leczenia dofetilid [21]. W Polsce do kardiowersji farmakologicznej wykorzystuje się także antazolinę, choć jej nie ujęto w obowiązujących wytycznych [22]. Kardiowersja elektryczna polega na jednoczasowej depolaryzacji wszystkich komórek mięśnia sercowego, co pozwala na przejęcie rytmu przez ośrodek o najszybszym automatyzmie, czyli w warunkach fizjologicznych przez węzeł zatokowy. Zabieg wykonuje się w krótkotrwałym znieczuleniu ogólnym. W obowiązujących wytycznych nie sprecyzowano, jakiej energii impulsu należy użyć, ale podkreśla się większą skuteczność prądu dwufazowego z początkową energią impulsu 150-200 J, z ewentualnym stopniowym zwiększaniem energii w kolejnych próbach [23]. Dowiedziono, że generatory dwufazowe są skuteczniejsze i wywołują mniejsze uszkodzenie miokardium [24]. Wożakowska-Kapłon i wsp. [25] wykazali, że, aby zwiększyć szanse na skuteczną kardiowersję elektryczną, energia impulsu dwufazowego powinna być dostosowana do czasu trwania AF i zaproponowali początkową dawkę energii $200 \mathrm{~J}$ w przypadku dłużej trwających epizodów arytmii. Elektrody defibrylatora częściej przykłada się w pozycji przednio-bocznej, choć wykazano, że przyłożenie przednio-tylne jest skuteczniejsze w przywracaniu rytmu zatokowego [26]. Zgodnie z wytycznymi istnieje możliwość podania leków przeciwarytmicznych przed planowaną kardiowersją elektryczną w celu zwiększenia prawdopodobieństwa przywrócenia i utrzymania rytmu zatokowego - dotyczy to propafenonu, amiodaronu, flekainidu i ibutilidu. Podobne właściwości wykazano także w przypadku wernakalantu, a szczególnie u pacjentów z nawrotem arytmii po ablacji AF [27]. W każdym przypadku podejmowania próby kardiowersji należy pamiętać o konieczności zastosowania leczenia przeciwkrzepliwego.

Badaniem dotyczącym wyboru rodzaju kardiowersji u pacjentów z AF jest ACWAS (Acute Cardioversion Versus Wait And See-approach for Symptomatic Atrial Fibrillation in the Emergency Department) [28]. Celem tego badania jest porównanie dwóch strategii postępowania u pacjentów z ostrym, objawowym, napadowym AF. Pierwsza z nich to pilna kardiowersja elektryczna lub farmakologiczna, druga natomiast polega na zastosowaniu jedynie leków kontrolujących częstość rytmu komór i przyjęcie pozycji wyczekującej. W przypadku utrzymywania się AF przez 48 godzin zostanie wykonana kardiowersja. Hipotezą badania jest założenie, że strategia wyczekiwania jest efektywniejsza, bezpieczniejsza, efektywna pod względem kosztów i poprawia jakość życia. Punktem pierwszorzędowym jest obecność rytmu zatokowego w obserwacji 4-tygodniowej. Zaplanowano włączenie 437 pacjentów; badanie ma się zakończyć w połowie 2019 roku [28].

\section{Metody utrzymania rytmu zatokowego}

U pacjentów, u których uzyskano powrót rytmu zatokowego, kolejnym krokiem jest ustalenie metody terapii w celu utrzymania tego rytmu. Pozostaje wybór: 1) zastosować jedynie leki spowalniające częstość rytmu komór w przypadku kolejnego napadu AF, 2) zastosować leki przeciwarytmiczne, 3) wykonać ablację AF. Spośród leków przeciwarytmicznych, które można zastosować w celu długotrwałego utrzymania rytmu zatokowego, do dyspozycji są propafenon, sotalol, amiodaron i dronedaron. W wytycznych amerykańskich dotyczących utrzymania rytmu zatokowego dopuszczono także zastosowanie dizopiramidu, chinidyny oraz dofetilidu [21]. Dzięki zastosowaniu leków przeciwarytmicznych możliwe jest zwiększenie o 50\% liczby pacjentów z utrzymanym rytmem zatokowym [1]. Ze względu na fakt, że leczenie przeciwarytmiczne stosuje się wyłącznie w celu zmniejszenia objawów wynikających z napadów AF, oraz liczne doniesienia o możliwym szkodliwym działaniu leków przeciwarytmicznych podstawowym kryterium, jakim należy się kierować przy doborze tych leków, jest bezpieczeństwo pacjentów. Istnieje także możliwość krótkoterminowego przyjmowania leków przeciwarytmicznych po kardiowersji i takie postępowanie oceniono odnośnie do flekainidu [29]. U osób bez strukturalnej choroby serca można zastosować dronedaron, propafenon, flekainid oraz sotalol, przy czym użycie tego ostatniego wymaga dokładnej oceny ryzyka proarytmicznego. Pacjent ze stabilną chorobą wieńcową bez niewydolności serca może przyjmować dronedaron, sotalol oraz amiodaron. Chory z niewydolnością krążenia, wymagający leczenia przeciwarytmicznego, może przyjmować jedynie amiodaron.

Alternatywą dla leków przeciwarytmicznych w przypadku wyboru strategii utrzymania rytmu zatokowego jest ablacja AF. W wytycznych dotyczących klasy I zaleca się zastosowanie ablacji AF jako leczenie drugiego wyboru w przypadku nieskuteczności farmakoterapii przeciwarytmicznej [1]. W ramach klasy zaleceń Ila ablację AF można przeprowadzić jako leczenie z wyboru zamiast farmakoterapii. Zabieg ten wykonuje w doświadczonym ośrodku odpowiednio wyszkolony elektrofizjolog 
u pacjentów z objawowym AF, którzy preferują strategię utrzymania rytmu zatokowego. Celem ablacji AF jest izolacja żył płucnych za pomocą energii prądu o częstotliwości radiowej (RF, radiofrequency) lub krioablacji. U pacjentów z przetrwałym lub długotrwale przetrwałym, objawowym, opornym na farmakoterapię AF należy rozważyć ablację przezcewnikową lub chirurgiczną, ale w tym przypadku wymagana jest konsultacja tak zwanej kardiogrupy (heart team) ds. leczenia AF.

Aktualnie najlepiej udokumentowaną metodą ablacji AF pozostaje całkowita izolacja żył płucnych. Opracowano kilka technologii wykorzystywanych do tego zabiegu, przy czym najpowszechniej stosowane są ablacja energią RF i krioablacja. Dodatkowe strategie wykorzystywane w trakcie zabiegu AF, tj. ablacja złożonych, frakcjonowanych elektrogramów (CFAE, complex fractionated atrial electrograms), ablacja rotorów, dodatkowe linijne ablacje w obrębie lewego i/lub prawego przedsionka, nie są zalecane w trakcie pierwszego zabiegu ablacji AF. Podkreślono także fakt znacznie większego odsetka wtórnych arytmii po ablacjach uzupełnianych o dodatkowe aplikacje w obrębie lewego przedsionka. $Z$ tego powodu dodatkowe strategie ablacji AF są obecnie zarezerwowane dla pacjentów, u których AF nawróciło i zostali zakwalifikowani do ponownego zabiegu ablacji AF. Mimo ogromnego postępu technologicznego w ostatnich kilkunastu latach z aktualnych badań dotyczących długoterminowej skuteczności ablacji AF wynika, że większość pacjentów poddanych takiemu postępowaniu będzie wymagało ponownych interwencji zabiegowych $[30,31]$. Skuteczność zabiegu ablacji AF w ogromnej mierze zależy od wieku pacjenta, czasu trwania arytmii, długości napadów oraz obecności strukturalnej choroby serca [32]. W przypadku napadowego AF skuteczność ocenia się na 70\%, natomiast przetrwałego - już na 50\% w obserwacji kilkunastomiesięcznej [29, 30, 33]. W obserwacji kilkuletniej zabieg ablacji pozwala na uzyskanie remisji choroby u około $50 \%$ pacjentów.

W odniesieniu do utrzymania rytmu zatokowego toczy się najwięcej badań klinicznych. Część z nich opisano powyżej (CABANA oraz EAST). W badaniach dotyczących leczenia farmakologicznego AF główny nacisk kładzie się na poszukiwanie leków hamujących ultraszybki prąd potasowy ( $I_{\text {kur }}$ ). Część z tych leków przeszła już pierwsze fazy badań klinicznych i można oczekiwać, że w najbliższym czasie zostaną opublikowane pierwsze doniesienia z badań nad pacjentami z AF. Najbardziej zaawansowane badania trwają nad lekiem o nazwie XEN-D103, ale sugeruje się, że korzyści z jego stosowania będą mogli odnieść chorzy bez dokonanego remodelingu mięśniówki przedsionków [34].

Toczą się także badania kliniczne dotyczące dodatkowych strategii ablacji AF w celu poprawienia wyników zabiegu i są to badania o akronimach SurHyb (Sequential Hybrid CryoMaze Ablation versus Surgical CryoMaze Alone for the
Treatment of Atrial Fibrillation) oraz aMAZE (LAA Ligation Adjunctive to PVI for Persistent or Longstanding Persistent Atrial Fibrillation). Badanie SurHyb zaprojektowano z myślą o pacjentach z przetrwałym i długotrwale przetrwałym AF [35]. Zadaniem autorów tego badania jest porównanie strategii leczenia zabiegowego AF w postaci operacji CryoMaze z zabiegiem hybrydowym składającym się z operacji CryoMaze i następnie uzupełnionnym zabiegiem ablacji przezcewnikowej prądem RF po 3 miesiącach od operacji CryoMaze. Pierwszorzędowym punktem końcowym jest brak arytmii przedsionkowej u pacjentów nieprzyjmujących leków przeciwarytmicznych. Skuteczność ablacji będzie oceniana w 7-dniowym badaniu holterowskim po 3, 6, 12, 18, i 24 miesiącach od ablacji. Zaplanowano włączenie 260 pacjentów [35].

Badaniem prowadzonym w celu oceny strategii poprawiających skuteczność ablacji AF u pacjentów z przetrwałym i długotrwale przetrwałym AF jest również badanie aMAZE [36]. Przyczynkiem do niego była obserwacja, że w przypadku przetrwałego lub długotrwale przetrwałego AF trigery i/lub substrat AF często są zlokalizowane w uszku lewego przedsionka. Badanie to służy porównaniu strategii zabiegowego leczenia AF, tj. izolacji żył płucnych za pomocą energii RF oraz zamknięcia uszka lewego przedsionka za pomocą systemu LARIAT i następnie przezcewnikowej izolacji żył płucnych za pomocą energii RF. Po 90 dniach od ablacji wszystkie leki przeciwarytmiczne zostaną odstawione. Przewidziano włączenie 600 pacjentów. Punktem pierwszorzędowym jest brak epizodów AF, trzepotania przedsionków (AFL, atrial flutter) czy częstoskurczu przedsionkowego (AT, atrial tachycardia) dłuższych niż $30 \mathrm{~s}$ w obserwacji 12-miesięcznej ocenianych za pomocą 24 godzinnego badania EKG metoda Holtera, które będą wykonane w 6. i 12. miesiącu po ablacji izolacji żył płucnych. Dodatkowo pacjenci, którzy zgłoszą objawy arytmii, zostaną zaopatrzeni w monitory zdarzeń. Zakończenie badania zaplanowano na grudzień 2018 roku [36].

Badaniem służącym ocenie wpływu hartowania niedokrwieniem na możliwość wyindukowania i podtrzymania AF $w$ trakcie ablacji AF jest RIPPAF (Effect of Remote Ischemic Preconditioning on Electrophysiological and Biomolecular Parameters in Non-valvular Paroxysmal Atrial Fibrillation) [37]. Zaprojektowano je na podstawie obserwacji, że hartowanie niedokrwieniem przed operacją kardiochirurgiczną istotnie zmniejsza częstość występowania nowo rozpoznanych AF. W protokole zakłada się wywołanie niedokrwienia kończyny górnej za pomocą sfingomanometru przed zabiegiem ablacji i w jego trakcie. Następnie w trakcie ablacji, za pomocą szybkiej stymulacji przedsionkowej, zostanie podjęta próba wywołania AF. Zaplanowano włączenie 146 pacjentów, a zakończenie badania wyznaczono na wrzesień 2018 roku. 


\section{Leczenie przeciwkrzepliwe przed kardiowersją}

Mimo braku kontrolowanych, dużych badań klinicznych w wytycznych jednoznacznie wskazano, w jaki sposób zastosować leczenie przeciwkrzepliwe u pacjentów zakwalifikowanych do kardiowersji. Pacjentowi nieprzyjmującemu przewlekle doustnego antykoagulantu, u którego wystąpiło AF i chorego tego zakwalifikowano do strategii utrzymania rytmu zatokowego, należy jak najwcześniej podać heparynę lub leki przeciwzakrzepowe niebędące antagonistami witaminy K (NOAC, non-vitamin K oral anticoagulants) niezależenie od ryzyka powikłań zakrzepowo-zatorowych. Następne decyzje zależą od czasu trwania napadu AF. Jeżeli w sposób pewny można stwierdzić, że napad AF trwa krócej niż 48 godzin, to po podaniu heparyny lub NOAC można podjąć próbę kardiowersji farmakologicznej lub elektrycznej. W przypadku pewności co do tego, jak długo trwa napad AF lub wiedzy, że AF trwa dłużej niż 48 godzin, do wyboru są dwie strategie. Pierwsza, powszechniej wykorzystywana, to zastosowanie skutecznego leczenia przeciwkrzepliwego przez co najmniej 3 tygodnie i wykonanie kardiowersji po tym okresie. Drugą strategia jest wykonanie przezprzełykowego badania echokardiograficznego (TOE, transoesophageal echocardiography) w celu wykluczenia skrzepliny w sercu i wykonanie kardiowersji w przypadku niestwierdzenia materiału zatorowego. Po wykonanej skutecznej kardiowersji u pacjentów nieobciążonych czynnikami ryzyka epizodów zakrzepowo-zatorowych należy kontynuować terapię przeciwkrzepliwą przez 4 tygodnie, a u pacjentów obarczonych czynnikami ryzyka epizodów zakrzepowo-zatorowych terapia jest bezterminowa niezależnie od utrzymania rytmu zatokowego. Jeżeli w TOE uwidoczni się skrzeplinę, to zaleca się co najmniej 3-tygodniowe leczenie przeciwkrzepliwe, a następnie ponowne wykonanie TOE w celu potwierdzenia rozpuszczenia skrzepliny. U pacjentów z napadem AF w trakcie skutecznego leczenia przeciwkrzepliwego trwającego minimum 3 tygodnie kardiowersję można wykonać bez odraczania zabiegu.

Lekami z grupy NOAC, które przebadano w kontrolowanych badaniach klinicznych zaprojektowanych do przygotowania pacjentów do kardiowersji AF, są riwaroksaban (badanie X-VeRT [Explore the Efficacy and Safety of Once-daily Oral Rivaroxaban for the Prevention of Cardiovascular Events in Subjects With Nonvalvular Atrial Fibrillation Scheduled for Cardioversion]) [38], edoksaban (badanie ENSURE-AF [Edoxaban versus enoxaparin-warfarin in patients undergoing cardioversion of atrial fibrillation]) [39] oraz apiksaban (badanie EMANATE [Apixaban lowers stroke risk in atrial fibrillation patients undergoing cardioversion]) [40] (wyniki badania EMANATE przedstawiono podczas kongresu ESC w BarceIonie w 2017 r.). W badaniach tych wykazano, że leki te są równie skuteczne pod kątem profilaktyki incydentów zakrzepowo-zatorowych oraz równie bezpieczne jak antagoniści witaminy K (VKA, vitamin Kantagonist) pod kątem powikłań krwotocznych. Istotną przewagą zastosowania NOAC w tych badaniach był skrócony czas do bezpiecznego przygotowania pacjentów do kardiowersji w porównaniu z grupą pacjentów przyjmujących VKA. Dane w przypadku dabigatranu, który jako pierwszy z NOAC umieszczono w wytycznych do zastosowania u chorego zakwalifikowanego do kardiowersji elektrycznej, pochodzą z subanalizy badania RE-LY (Randomized Evaluation of Long-term anticoagulant therapY), w którym 1270 pacjentów poddano 1983 kardiowersjom i nie stwierdzono różnicy w zakresie powikłań zakrzepowo-zatorowych między grupą leczoną dabigatranem w dawce 2 razy 110 mg lub 2 razy 150 mg a leczonymi warfaryną [41].

Na podstawie metaanaliz badań nad NOAC, rejestrów i dużych jednoośrodkowych obserwacji z wykorzystaniem wszystkich NOAC przyjęto efekt klasy dla tych leków i w wytycznych dotyczących przygotowania przeciwzakrzepowego pacjentów zakwalifikowanych do kardiowersji wymieniono grupę NOAC jako całość bez wyszczególnienia leków.

Także w charakterystykach produktów leczniczych riwaroksabanu, apiksabanu i dabigatranu zapisano możliwość wykorzystania tych leków w przygotowaniu pacjenta do kardiowersji.

\section{Leczenie przeciwkrzepliwe a ablacja AF}

W przypadku leczenia przeciwkrzepliwego i ablacji AF wyraźnie podkreśla się zbyt małą liczbę kontrolowanych badań klinicznych, na podstawie których można stworzyć konkretne zalecenia.

W obowiązujących wytycznych dotyczących leczenia AF z użyciem NOAC jedynie riwaroksaban wymienia się jako lek przebadany u pacjentów, u których nieprzerwanie kontynuowano leczenie $w$ trakcie zabiegu ablacji i porównano go z VKA, wykazując podobną skuteczność i bezpieczeństwo leku (badanie VENTURE-AF [A randomised, open-label, active-controlled multicentre study to evaluate the safety of rivaroxaban and vitamin $K$ antagonists in subjects undergoing catheter ablation for atrial fibrillation]) [42]. W kwietniu bieżącego roku ukazały się wyniki badania RE-CIRCUIT (Randomized Evaluation of Dabigatran Etexilate Compared to Warfarin in Pulmonary Vein Ablation: Assessment of an Uninterrupted Periprocedural Anticoagulation Strategy), w którym oceniano okołozabiegowe leczenie przeciwkrzepliwe i porównywano nieprzerwane stosowanie dabigatranu $(2 \times 150 \mathrm{mg}$ ) i warfaryny (INR 2-3), stwierdzając mniejszą liczbę powikłań krwotocznych, tamponad i krwiaków podudzia w przypadku stosowania dabigatranu przy podobnej częstości powikłań zakrzepowo-zatorowych [43]. Wartym podkreślenia jest fakt, że w grupie 635 pacjentów, u których wykonano ablację AF, 
w badaniu RE-CIRCUIT epizod zakrzepowo-zatorowy stwierdzono tylko u jednego pacjenta, co stanowi 0,15\% badanej populacji, i to w grupie leczonej warfaryną.

W obowiązujących wytycznych dotyczących leczenia AF leczenie przeciwkrzepliwe w okresie okołozabiegowym omówiono dość nieprecyzyjnie. Zaleca się stosowanie terapii przeciwkrzepliwej przez co najmniej 8 tygodni u pacjentów po ablacji przezcewnikowej lub chirurgicznej. Ponadto rekomenduje się bezterminowe stosowanie leczenia przeciwkrzepliwego u pacjentów obciążonych dużym ryzykiem powikłań zakrzepowo-zatorowych niezależenie od skuteczności zabiegu ablacji. Autorzy wytycznych sugerują także, by kontynuować leczenie przeciwkrzepliwe VKA lub NOAC podczas zabiegu ablacji. W wytycznych znajdują się również informacje o konieczności podawania heparyny niefrakcjonowanej (UFH, unfractionated heparin) podczas zabiegu ablacji, tak aby aktywowany czas krzepnięcia (ACT, activated clotting time) wynosił co najmniej 300 s. W 2015 roku Sticherling i wsp. [44], pod auspicjami European Heart Rhythm Association (EHRA), Heart Rhythm Society (HRS) oraz Asia Pacific Heart Rhythm Society (APHRS), opublikowali stanowisko ekspertów dotyczące leczenia przeciwkrzepliwego u pacjentów poddanych ablacji, w którym opisano poszczególne etapy przygotowania i wykonania ablacji AF. W 2016 roku na łamach „Folia Cardiologica" ukazało się stanowisko ekspertów Sekcji Farmakoterapii Sercowo-Naczyniowej Polskiego Towarzystwa Kardiologicznego dotyczące NOAC [45]. W dokumencie tym zaproponowano, aby u wszystkich pacjentów kwalifikowanych do ablacji AF włączyć NOAC 3 tygodnie przed zabiegiem, a przerwać ich stosowanie 24 godziny przed ablacją (lub wcześniej zależnie od funkcji nerek). U pacjentów, u których istnieje jakakolwiek wątpliwość dotycząca leczenia przeciwkrzepliwego, należy wykonać TOE przez zabiegiem.

Badaniami, których celem jest ocena leczenia przeciwkrzepliwego w okresie okołozabiegowym izolacji żył płucnych, są AXAFA (Apixaban During Atrial Fibrillation Catheter Ablation: Comparison to Vitamin K Antagonist Therapy) oraz ODIn-AF (Prevention of Silent Cerebral Thromboembolism by Oral Anticoagulation with Dabigatran after Pulmonary Vein Isolation for Atrial Fibrillation). Badanie AXAFA służy porównaniu stosowania doustnych leków przeciwkrzepliwych (apiksaban v. VKA) w trakcie ablacji AF [46]. W tym przypadku badaniu podlega teza, czy apiksaban jest równie skuteczny jak VKA w prewencji powikłań okołozabiegowych, takich jak zgon z jakiejkolwiek przyczyny, udar niedokrwienny i krwotoczny mózgu oraz istotne krwawienie. Dodatkowo jednym z drugorzędowych punktów końcowych jest występowanie „niemych” zmian naczyniowych w mózgu wykrywanych metodą rezonansu magnetycznego (MRI, magnetic resonance imaging). Dozwolono stosowanie dowolnego VKA (warfaryna, acenoku- marol, fenoprokumon, fluindion). Zakończenie badania zaplanowano na koniec 2017 roku.

W wytycznych dotyczących leczenia AF z 2016 roku zalecono kontynuowanie leczenia przeciwkrzepliwego bezterminowo u pacjentów obciążonych wysokim ryzykiem powikłań zakrzepowo-zatorowych i po skutecznym zabiegu ablacji AF mimo braku dowodów na skuteczność takiego postępowania. W celu oceny słuszności tego postępowania zaprojektowano badanie ODIn-AF [47]. Ocenia się w nim, czy odstawienie dabigatranu u pacjentów po skutecznym zabiegu ablacji AF doprowadzi do zwiększonej częstości powikłań zakrzepowo-zatorowych. W badaniu przewidziano wykonanie MRI mózgu 3 miesiące po ablacji AF, a następnie pacjenci zostaną poddani randomizacji do grupy przyjmującej dabigatran lub placebo, po czym po 12 miesiącach ponownie zostanie wykonane MRI mózgu. Koniec badania zaplanowano na sierpień 2019 roku.

\section{Leczenie uzupełniające (upstream therapy)}

Badania dotyczące przeciwarytmicznego działania leków nieprzeciwarytmicznych, tj. inhibitorów konwertazy angiotensyny (ACE, angiotensin-converting enzyme), antagonistów receptorów $\mathrm{AT}_{1}$ angiotensyny II (ARB, angiotensin receptor blockers), leków blokujących receptory adrenergiczne, u chorych z AF wskazują, że są one skuteczne w prewencji pierwotnej nowo rozpoznanego AF u pacjentów z niewydolnością serca ze zmniejszoną frakcją wyrzutową lewej komory i pacjentów z nadciśnieniem tętniczym, szczególnie z istotnym przerostem, ale w prewencji wtórnej są one nieskuteczne. Leki te należy zatem stosować w leczeniu choroby podstawowej, tj. niewydolności krążenia lub nadciśnienia tętniczego, zmniejszając tym samym ryzyko nowo rozpoznanego $A F$, ale jeżeli AF wystąpi, to leki te nie obniżają ryzyka kolejnych napadów arytmii. Jedynie u pacjentów po kardiowersji zastosowanie inhibitora ACE lub ARB łącznie z lekami antyarytmicznymi może zmniejszyć częstość kolejnych napadów arytmii. Stosowanie leków blokujących receptor adrenergiczny u pacjentów z niewydolnością krążenia bez AF zmniejsza u nich częstość nowo rozpoznanego $A F$, ale niesie ze sobą ryzyko nierozpoznania lub późnego rozpoznania AF z powodu częstszego występowania bezobjawowych napadów arytmii. W odniesieniu do statyn, wielonienasyconych kwasów tłuszczowych oraz eplerenonu dane nie są wystarczające, aby zalecić ich stosowanie u pacjentów z izolowanym AF.

Badanie, którego celem pozostaje ocena, czy terapia uzupełniająca jest skuteczna w prewencji wtórnej napadowego AF, to VF-HT-AF (Upstream therapeutic strategies of Valsartan and Fluvastatin on Hypertensive patients with non-permanent Atrial Fibrillation) [48]. Jest w nim oceniany wpływ leczenia walsartanem i fluwastatyna na pacjentów z nadciśnieniem tętniczym i AF. Punktami końcowymi są ładunek AF oceniany w 7-dniowym 
monitorowaniu EKG oraz progresja napadowego AF do formy przetrwałej lub utrwalonej. Okres obserwacji wynosi 2 lata. Zaplanowano włączenie 1879 pacjentów z 15 ośrodków w Chinach.

\section{Podsumowanie}

Mimo zwiększającej się lawinowo liczby doniesień na temat leczenia AF nadal istnieją luki w dowodach dotyczących pacjentów z tym rodzajem arytmii. Choć, bez wątpienia, najlepiej zbadanym obszarem dotyczącym AF jest leczenie przeciwkrzepliwe, to nadal wiele jego aspektów pozostaje opartych na opinii ekspertów lub pojedynczych, małych doniesieniach. Obecnie u pacjentów z AF tylko leczenie przeciwkrzepliwe doczekało się miana terapii poprawiającej przeżycie pacjentów. Strategia utrzymania rytmu zatokowego, mimo kilku wartościowych doniesień, pozostaje terapią przynoszącą poprawę „jedynie” w zakresie objawów. Toczące się badania pozwolą na lepsze zrozumienie patofizjologii tej arytmii oraz na optymalizację leczenia za pomocą farmakoterapii antyarytmicznej oraz ablacji.

\section{Konflikt interesów}

BWK - honoraria za wykłady dla firm: Egis, Krka, MSD, Mylan, Servier.

\section{Abstract}

The main therapeutic problem in patients with atrial fibrillation (AF), besides determining indications for anticoagulant therapy, is the choice of rhythm control strategy vs rate control strategy. The 2016 guidelines recommend choosing rhythm control strategy "only" in order to reduce the symptoms resulting from arrhythmia. Previous studies comparing these treatment strategies in patients with AF did not reveal the advantage of one strategy over the other. In multicenter studies, such as AFFIRM, RACE, STAFF, PIAF, HOT CAFE, there were no differences between both strategies in terms of mortality and cardiovascular morbidity, although many post-hoc analyzes showed evidence of superiority of rhythm control strategies, taking into account so called soft endpoints, such as improving physical performance or humoral profile. Although current guidelines recommend a paradigm of maintaining sinus rhythm "only" to improve patients' symptoms, observational studies show that patients with restored and maintained sinus rhythm are characterized by a better prognosis. The article presents the current state of knowledge regarding the choice of treatment strategy in patients with non-valvular AF.

Key words: atrial fibrillation, cardioversion, antiarrhythmic agents, oral anticoagulants

Folia Cardiologica 2017; 12, 6: 570-579

\section{Piśmiennictwo}

1. Kirchhof P, Benussi S, Kotecha D, et al. 2016 ESC Guidelines for the management of atrial fibrillation developed in collaboration with EACTS. Eur Heart J. 2016; 37(38): 2893-2962, doi: 10.1093/ /eurheartj/ehw210, indexed in Pubmed: 27567408.

2. Wozakowska-Kaplon B, Opolski G. Atrial natriuretic peptide level after cardioversion of chronic atrial fibrillation. Int J Cardiol. 2002; 83(2): 159-165, doi: 10.1016/s0167-5273(02)00066-9, indexed in Pubmed: 12007688.

3. Wozakowska-Kapłon B, Opolski G. Concomitant recovery of atrial mechanical and endocrine function after cardioversion in patients with persistent atrial fibrillation. J Am Coll Cardiol. 2003; 41(10): 1716-1720, doi: 10.1016/s0735-1097(03)00306-1, indexed in Pubmed: 12767653.

4. Wozakowska-Kapłon B, Opolski G, Janion M. trial natriuretic peptide before and after cardioversion of persistent atrial fibrillation. Kardiol Pol. 2003; 58(4): 255-263, indexed in Pubmed: 14517556.

5. Wozakowska-Kapłon B, Opolski G. Improvement in exercise performance after successful cardioversion in patients with persistent atrial fibrillation and symptoms of heart failure. Kardiol Pol. 2003; 59(9): 213-223, indexed in Pubmed: 14618198.
6. Suman-Horduna I, Roy D, Frasure-Smith N, et al. AF-CHF Trial Investigators. Quality of life and functional capacity in patients with atrial fibrillation and congestive heart failure. J Am Coll Cardiol. 2013; 61(4): 455-460, doi: 10.1016/j.jacc.2012.10.031, indexed in Pubmed: 23265334.

7. Keating RJ, Gersh BJ, Hodge DO, et al. Effect of atrial fibrillation pattern on survival in a community-based cohort. Am J Cardiol. 2005; 96(10): 1420-1424, doi: 10.1016/j.amjcard.2005.07.050, indexed in Pubmed: 16275191.

8. Lubitz SA, Moser C, Sullivan L, et al. Atrial fibrillation patterns and risks of subsequent stroke, heart failure, or death in the community. J Am Heart Assoc. 2013; 2(5): e000126, doi: 10.1161/JAHA.113.000126, indexed in Pubmed: 24002369.

9. Ionescu-Ittu R, Abrahamowicz M, Jackevicius CA, et al. Comparative effectiveness of rhythm control vs rate control drug treatment effect on mortality in patients with atrial fibrillation. Arch Intern Med. 2012; 172(13): 997-1004, doi: 10.1001/archinternmed.2012.2266, indexed in Pubmed: 22664954.

10. Corley SD, Epstein AE, DiMarco JP, et al. AFFIRM Investigators. Relationships between sinus rhythm, treatment, and survival in the Atrial 
Fibrillation Follow-Up Investigation of Rhythm Management (AFFIRM) Study. Circulation. 2004; 109(12): 1509-1513, doi: 10.1161/01. CIR.0000121736.16643.11, indexed in Pubmed: 15007003.

11. Saliba W, Schliamser JE, Lavi I, et al. Catheter ablation of atrial fibrillation is associated with reduced risk of stroke and mortality: a propensity score-matched analysis. Heart Rhythm. 2017; 14(5): 635-642, doi: 10.1016/j.hrthm.2017.02.001, indexed in Pubmed: 28189823.

12. Wyse DG, Waldo AL, DiMarco JP, et al. Atrial Fibrillation Follow-up Investigation of Rhythm Management (AFFIRM) Investigators. A comparison of rate control and rhythm control in patients with atrial fibrillation. N Engl J Med. 2002; 347(23): 1825-1833, doi: 10.1056/ /NEJMoa021328, indexed in Pubmed: 12466506.

13. Lafuente-Lafuente C, Valembois L, Bergmann JF, et al. Antiarrhythmics for maintaining sinus rhythm after cardioversion of atrial fibrillation. Cochrane Database Syst Rev. 2015(3): CD005049, doi: 10.1002/14651858.CD005049.pub4, indexed in Pubmed: 25820938.

14. Hohnloser SH, Crijns HJ, van Eickels M, et al. ATHENA Investigators. Effect of dronedarone on cardiovascular events in atrial fibrillation. N Engl J Med. 2009; 360(7): 668-678, doi: 10.1056/NEJMoa0803778, indexed in Pubmed: 19213680.

15. Hunter RJ, McCready J, Diab I, et al. Maintenance of sinus rhythm with an ablation strategy in patients with atrial fibrillation is associated with a lower risk of stroke and death. Heart. 2012; 98(1): 48-53, doi: 10.1136/heartjnl-2011-300720, indexed in Pubmed: 21930724.

16. Lin YJ, Chao TF, Tsao HM, et al. Successful catheter ablation reduces the risk of cardiovascular events in atrial fibrillation patients with CHA2DS2-VASc risk score of 1 and higher. Europace. 2013; 15(5): 676-684, doi: 10.1093/europace/eus336, indexed in Pubmed: 23193161.

17. Bunch TJ, May HT, Bair TL, et al. Atrial fibrillation ablation patients have long-term stroke rates similar to patients without atrial fibrillation regardless of CHADS2 score. Heart Rhythm. 2013; 10(9): 1272-1277, doi: 10.1016/j.hrthm.2013.07.002, indexed in Pubmed: 23835257.

18. ClinicalTrials.gov. Catheter Ablation vs Anti-arrhythmic Drug Therapy for Atrial Fibrillation Trial (CABANA). https: //clinicaltrials.gov/ct2/ /show/NCT00911508 (15.11.2017).

19. ClinicalTrials.gov Early Treatment of Atrial Fibrillation for Stroke Prevention Trial (EAST). https://clinicaltrials.gov/ct2/show/NCT01288352 (15.11.2017).

20. Ciszewski J, Maciag A, Kowalik I, et al. Comparison of the rhythm control treatment strategy versus the rate control strategy in patients with permanent or long-standing persistent atrial fibrillation and heart failure treated with cardiac resynchronization therapy - a pilot study of Cardiac Resynchronization in Atrial Fibrillation Trial (Pilot-CRAfT): study protocol for a randomized controlled trial. Trials. 2014; 15: 386, doi: 10.1186/1745-6215-15-386, indexed in Pubmed: 25281275.

21. Al-Khatib SM, Arshad A, Balk EM, et al. American College of Cardiology/ /American Heart Association Task Force on Practice Guidelines, ACC/ /AHA Task Force Members, ACC/AHA Task Force Members. 2014 AHA/ /ACC/HRS guideline for the management of patients with atrial fibrillation: a report of the American College of Cardiology/American Heart Association Task Force on practice guidelines and the Heart Rhythm Society. Circulation. 2014; 130(23): e199-e267, doi: 10.1161/CIR. 0000000000000041 , indexed in Pubmed: 24682347.

22. Farkowski MM, Maciąg A, Żurawska M, et al. Comparative effectiveness and safety of antazoline-based and propafenone-based strategies for pharmacological cardioversion of short-duration atrial fibrillation in the emergency department. Pol Arch Med Wewn.
2016; 126(6): 381-387, doi: 10.20452/pamw.3452, indexed in Pubmed: 27362390.

23. Reiffel JA. Cardioversion for atrial fibrillation: treatment options and advances. Pacing Clin Electrophysiol. 2009; 32(8): 1073-1084, doi: 10.1111/j.1540-8159.2009.02441.x, indexed in Pubmed: 19659629.

24. Kosior DA, Opolski G, Tadeusiak W, et al. Serum troponin I and myoglobin after monophasic versus biphasic transthoracic shocks for cardioversion of persistent atrial fibrillation. Pacing Clin Electrophysiol. 2005; 28(Suppl 1): S128-S132, doi: 10.1111/j.1540-8159.2005.00038.x, indexed in Pubmed: 15683479.

25. Wozakowska-Kaplon B, Janion M, Sielski J, et al. Efficacy of biphasic shock for transthoracic cardioversion of persistent atrial fibrillation: can we predict energy requirements? Pacing Clin Electrophysiol. 2004; 27(6 Pt 1): 764-768, doi: 10.1111/j.1540-8159.2004.00525.x, indexed in Pubmed: 15189531.

26. Kirchhof P, Eckardt L, Loh P, et al. Anterior-posterior versus anterior-lateral electrode positions for external cardioversion of atrial fibrillation: a randomised trial. Lancet. 2002; 360(9342): 1275 -1279, doi: 10.1016/s0140-6736(02)11315-8, indexed in Pubmed: 12414201.

27. Müssigbrodt A, John S, Kosiuk J, et al. Vernakalant-facilitated electrical cardioversion: comparison of intravenous vernakalant and amiodarone for drug-enhanced electrical cardioversion of atrial fibrillation after failed electrical cardioversion. Europace. 2016; 18(1): 51-56, doi: 10.1093/europace/euv194, indexed in Pubmed: 26056189.

28. Acute Cardioversion Versus Wait And See-approach for Symptomatic Atrial Fibrillation in the Emergency Department (ACWAS). https://clinicaltrials.gov/ct2/show/NCT02248753 (15.11.2017).

29. Kirchhof $P$, Andresen D, Bosch R, et al. Short-term versus long-term antiarrhythmic drug treatment after cardioversion of atrial fibrillation (Flec-SL): a prospective, randomised, open-label, blinded endpoint assessment trial. Lancet. 2012; 380(9838): 238-246, doi: 10.1016/ /S0140-6736(12)60570-4, indexed in Pubmed: 22713626.

30. Wilber DJ, Pappone C, Neuzil P, et al. ThermoCool AF Trial Investigators. Treatment of atrial fibrillation with antiarrhythmic drugs or radiofrequency ablation: two systematic literature reviews and meta-analyses. Circ Arrhythm Electrophysiol. 2009; 2(4): 349-361, doi: 10.1161/CIRCEP.108.824789, indexed in Pubmed: 19808490.

31. Ganesan AN, Shipp NJ, Brooks AG, et al. Long-term outcomes of catheter ablation of atrial fibrillation: a systematic review and meta-analysis. J Am Heart Assoc. 2013; 2(2): e004549, doi: 10.1161/JAHA. 112.004549, indexed in Pubmed: 23537812.

32. Dagres N, Hindricks G, Kottkamp H, et al. Complications of atrial fibrillation ablation in a high-volume center in 1,000 procedures: still cause for concern? J Cardiovasc Electrophysiol. 2009; 20(9): 1014-1019, doi: 10.1111/j.1540-8167.2009.01493.x, indexed in Pubmed: 19490383.

33. Verma A, Jiang Cy, Betts TR, et al. STAR AF II Investigators. Approaches to catheter ablation for persistent atrial fibrillation. N Engl J Med. 2015; 372(19): 1812-1822, doi: 10.1056/NEJMoa1408288, indexed in Pubmed: 25946280.

34. Ravens U, Odening KE. Atrial fibrillation: therapeutic potential of atrial K+ channel blockers. Pharmacol Ther. 2017; 176: 13-21, doi: 10.1016/j.pharmthera.2016.10.003, indexed in Pubmed: 27742566.

35. Eisenberger M, Bulava A, Kautzner J, et al. Sequential Hybrid CryoMaze Ablation versus Surgical CryoMaze Alone for the Treatment of Atrial Fibrillation (SurHyb): study protocol for a randomized controlled trial. 
Trials. 2016; 17(1): 518, doi: 10.1186/s13063-016-1634-4, indexed in Pubmed: 27776530.

36. LAA Ligation Adjunctive to PVI for Persistent or Longstanding Persistent Atrial Fibrillation (aMAZE). https://clinicaltrials.gov/ct2/show/ /NCT02513797 (15.11.2017).

37. Kosiuk J, Milani R, Ueberham L, et al. Effect of remote ischemic preconditioning on electrophysiological and biomolecular parameters in nonvalvular paroxysmal atrial fibrillation (RIPPAF study): rationale and study design of a randomized, controlled clinical trial. Clin Cardiol. 2016; 39(11): 631-635, doi: 10.1002/clc.22584, indexed in Pubmed: 27775830.

38. Cappato R, Ezekowitz MD, Klein AL, et al. X-VeRT Investigators. Rivaroxaban vs. vitamin $\mathrm{K}$ antagonists for cardioversion in atrial fibrillation. Eur Heart J. 2014; 35(47): 3346-3355, doi: 10.1093/eurheartj/ /ehu367, indexed in Pubmed: 25182247.

39. Goette A, Merino JL, Ezekowitz MD, et al. ENSURE-AF investigators. Edoxaban versus enoxaparin-warfarin in patients undergoing cardioversion of atrial fibrillation (ENSURE-AF): a randomised, open-label, phase 3b trial. Lancet. 2016; 388(10055): 1995-2003, doi: 10.1016/ /S0140-6736(16)31474-X, indexed in Pubmed: 27590218.

40. Ezekowitz MD, Pollack CV, Sanders P, et al. Apixaban compared with parenteral heparin and/or vitamin $\mathrm{K}$ antagonist in patients with nonvalvular atrial fibrillation undergoing cardioversion: rationale and design of the EMANATE trial. Am Heart J. 2016; 179: 59-68, doi: 10.1016/j.ahj.2016.06.008, indexed in Pubmed: 27595680.

41. Prevention of Silent Cerebral Thromboembolism by Oral Anticoagulation With Dabigatran After Pulmonary Vein Isolation for Atrial Fibrillation (ODIn-AF). https://clinicaltrials.gov/show/NCT02067182 (15.11.2017).

42. Cappato R, Marchlinski FE, Hohnloser SH, et al. VENTURE-AF Investigators. Uninterrupted rivaroxaban vs. uninterrupted vitamin $\mathrm{K}$ antago- nists for catheter ablation in non-valvular atrial fibrillation. Eur Heart J. 2015; 36(28): 1805-1811, doi: 10.1093/eurheartj/ehv177, indexed in Pubmed: 25975659.

43. Calkins H, Willems S, Gerstenfeld EP, et al. RE-CIRCUIT Investigators. Uninterrupted dabigatran versus warfarin for ablation in atrial fibrillation. N Engl J Med. 2017; 376(17): 1627-1636, doi: 10.1056/ /NEJMoa1701005, indexed in Pubmed: 28317415.

44. Sticherling C, Marin F, Birnie D, et al. Antithrombotic management in patients undergoing electrophysiological procedures: a European Heart Rhythm Association (EHRA) position document endorsed by the ESC Working Group Thrombosis, Heart Rhythm Society (HRS), and Asia Pacific Heart Rhythm Society (APHRS). Europace. 2015; 17(8): 1197-1214, doi: 10.1093/europace/euv190, indexed in Pubmed: 26105732.

45. Kasprzak J, Dąbrowski R, Barylski M, et al. Doustne antykoagulanty nowej generacji - aspekty praktyczne. Stanowisko Sekcji Farmakoterapii Sercowo-Naczyniowej Polskiego Towarzystwa Kardiologicznego. Folia Cardiol. 2016; 11(5): 377-393, doi: 10.5603/fc.2016.0064.

46. Apixaban During Atrial Fibrillation Catheter Ablation: Comparison to Vitamin K Antagonist Therapy (AXAFA). https://clinicaltrials.gov/ct2/ /show/NCT02227550 (15.11.2017).

47. Prevention of Silent Cerebral Thromboembolism by Oral Anticoagulation With Dabigatran After Pulmonary Vein Isolation for Atrial Fibrillation (ODIn-AF). https://clinicaltrials.gov/show/NCT02067182 (15.11.2017).

48. Qi WW, Liu T, Xu G, et al. Upstream therapeutic strategies of Valsartan and Fluvastatin on Hypertensive patients with non-permanent Atrial Fibrillation (VF-HT-AF): study protocol for a randomized controlled trial. Trials. 2015; 16: 336, doi: 10.1186/s13063-015-0836-5, indexed in Pubmed: 26248619. 